\title{
Research on the Modern Enlightenment of Mao Zedong Thought on Peasants from the Perspective of Rural Revitalization Strategy
}

\author{
Weina Dong \\ Xi'an Medical University \\ Xi'an, China 710021
}

\begin{abstract}
The people are an important driving force for social development and an important foundation for social stability. The issue of "agriculture, rural areas and farmers" is a key issue concerning the overall situation, stability, and development. The first generation of the central leadership of the party with Comrade Mao Zedong as the core attached great importance to the issue of "agriculture, rural areas and farmers" and made a series of arrangements for the deployment, made series of principles and policies and formed the Mao Zedong Thought on Pheasants in the specific practice of the revolution, which guided the Chinese farmers to achieve national independence and people's liberation. The rural revitalization strategy is an important strategic goal put forward by General Secretary Xi Jinping in the report of the 19th National Congress. It is an important part of Xi Jinping's thoughts on socialist farmers with Chinese characteristics in the new era. It is an important starting point for solving the issues concerning agriculture, rural areas and farmers and an important passage to address the contradiction between unbalanced and inadequate development and the people's ever-growing needs for a better life, as well as the ruling foundation of CPC to consolidate ruling in the countryside, and an important carrier to build a well-off society, build beautiful villages, and to realize the Two Centenary Goals. On the occasion of the 70th anniversary of the founding of the People's Republic of China, an in-depth discussion of Mao Zedong thought on farmers is of great guiding significance for the implementation of the rural revitalization strategy.
\end{abstract}

Keywords-rural revitalization strategy; farmers; Mao Zedong thought on farmers

\section{INTRODUCTION}

Generations of leaders of the Communist Party of China has highly valued the issue of "agriculture, rural areas and farmers". Since the 18th National Party Congress, The CPC central committee with Comrade Xi Jinping as the core has attached more importance to the issue of "agriculture, rural areas and farmers" and has introduced a series of policies to benefit farmers, and continued to deepen reform of the rural economic system. Major achievements have been made in China's agricultural development, and people's sense of happiness, gain and security has increased significantly.

In order to further promote the reform of rural economic system, finish the building of a moderately prosperous society in an all-round way, and realize the Chinese dream of the great rejuvenation of the Chinese nation, the 19th national congress of the CPC put forward the rural revitalization strategy for the first time and wrote it into the party constitution, proposing the general requirements of thriving businesses, pleasant living environment, social etiquette and civility, effective governance and prosperity. Opinions of the CPC Central Committee and the State Council on the Implementation of the Rural Revitalization Strategy, the "No. 1 central document" issued in 2018 made comprehensive deployment towards the rural revitalization strategy from several aspects including the significance, requirements and principles of implementing the rural revitalization strategy in the new era. On March 8, 2018, when participating in the deliberation of the Shandong delegation, it was proposed that rural revitalization was a comprehensive revitalization including industrial revitalization, talent revitalization, cultural revitalization, ecological revitalization, and organizational revitalization. In July 2018, General Secretary Xi Jinping made a major instruction on the implementation of the rural revitalization strategy. In 2019, the "No 1 central document" mentioned: "Adhering to the general policy of giving priority to the development of agriculture and rural areas and taking the strategy of rural revitalization as the starting point are the hard tasks that must be completed in completing the work on agriculture, rural areas and farmers of a moderately prosperous society in all respects". ${ }^{1}$ On March 10, 2019, during the deliberation of the Henan delegation, it's emphasized that the overall objective of the rural revitalization strategy is agricultural and rural modernization.

For whom is the revitalization, why revitalize, and what to revitalize? This is the main thread running through the implementation of the rural revitalization strategy. Man serves as the main force of social development. With the reform of China's economic system, a large number of peasants have flooded into cities, which has seriously led to the "hollowing" and decline of rural areas, the slow economic development, the slow construction of rural

Several Opinions of the Central Committee of the Communist Party of China and the State Council on Adhering to the Priority of Agricultural and Rural Development to Do a Good Job in the "Three Rural Issues". People's Daily, February 20, 2019. 
culture, the slow improvement of rural governance capacity, and the prominent contradiction between urban and rural dual structure. In this context, it is particularly important to revitalize the countryside, realize rural economic development, create and increase income for the people, and solve the issues concerning agriculture, rural areas and farmers.

\section{MaO ZEDONG'S ThOUght ON PEASANTS}

\section{A. Classic Marxist Writers' Theory on Farmers}

The farmer thoughts of Marx and Engels were produced and developed in the process of Marx and Engels leading the proletarian revolution. The farmer thoughts of Marx and Engels mainly include the nature of farmers, the role of farmers, and the establishment of cooperatives.

The nature of farmers: Marx and Engels attached great importance to the farmer issue. In The Communist Manifesto published in 1848, Marx spoke that in the struggle against the bourgeoisie, the farmer are conservative. In addition, Marx divided the farmer into middle class. In Revolution and Counter-Revolution: Or Germany in 1848, Engels divided the farmer class into four categories: wealthy farmers, small free farmers, feudal tenants, and agricultural workers. The role of farmers: Marx and Engels recognized the power of the framer. Marx mentioned in The Communist Manifesto: "Previously the lower middle classes — the small industrialists, the small traders, the small renter, the artisans, the pheasant - all these classes have descended into the ranks of the proletariat", arguing that the peasants have strengthened the power of the proletariat. Engels mentioned in the French-German Peasant Problem: "From Ireland to Sicily, from Andalusia to Russia and Bulgaria, peasants are very important factors in population, production and political power." 2 Questions about cooperatives: Marx and Engels advocated the establishment of cooperatives. They believe that cooperatives are important organizations for farmers to protect their own interests. The principle of equality and voluntariness shall be adhered to when farmers join cooperatives and they shall not be forced to join. Marx and Engels believed that cooperatives include cooperative factories, production cooperatives, and consumer cooperatives, etc., and the function of cooperative is to consolidate the worker-peasant alliance.

Lenin's thoughts on peasants inherited and developed Marx and Engels' thoughts on peasants, which mainly included the role of peasants, the classification of peasants, the cooperation of peasants and the education of peasants.

The role of farmers: During the October revolution, Lenin believed that peasants were an important force in the democratic revolution. After the October revolution, Lenin believed that peasants were reliable forces to rely on in socialist construction. After the victory of the October revolution, Russia faced a complicated and severe environment at home and abroad. Lenin implemented the

2 Selected Works of Marx and Engels, Vol. 4, Beijing: People's Publishing House, 1995, p. 484. wartime communism policy and the surplus grain collection system in agricultural products, which aroused the dissatisfaction of peasants. In the face of the reality, Lenin rethought and formulated the new economic policy, which improved the agricultural productivity, strengthened the enthusiasm of farmers in production, and consolidated the foundation of the alliance between workers and peasants. Lenin said: "The essence of the new economic policy is the alliance of the proletariat with the peasants, the union of the vanguard proletariat with the broad masses of peasants, and the highest principle of the dictatorship of the proletariat is to maintain the alliance of the proletariat with the peasants." ${ }^{3}$ The cooperation of farmers: Lenin advocated that peasants should be guided to the path of socialism by way of cooperation, various policies should be introduced to support the development of cooperatives, and the principle of respecting public opinion should be adhered to when peasants join cooperatives. The education of farmers: Lenin attaches great importance to cultural education for peasants, provided free compulsory education for men and women under the age of 16 , and actively recruited peasants into the national management team.

\section{ThE MAIN CONTENT OF MAO ZEDONG'S ThOUGHT ON PEASANT}

Mao Zedong's thought on peasant is an important part of Mao Zedong Thought. Mao Zedong inherited and developed the Marxist classic writer peasant thought. Mao Zedong's thought on peasant was formed and developed in the practice of Chinese revolution and construction, mainly including great importance should be attached to the status and the role of peasants, ideological and political education of the peasants, and the guidance of the peasants to take the road of cooperation. The in-depth study of Mao Zedong's thought on peasant has a constructive role in the current implementation of the rural revitalization strategy.

\section{A. Paying Attention to Farmers and Protecting Their Interests}

Whether before or after the founding of the People's Republic of China, the first generation of central collective leadership of the communist party of China with Comrade Mao Zedong as the core attached great importance to farmers and actively protected their interests. During the period of the democratic revolution, Mao Zedong pointed out: "In China, whenever armed struggle is mentioned, its essence is peasant war." ${ }^{4}$ Mao Zedong pointed out in the article National Revolution and Peasant Movement, that the problem of peasants was an important one in the national revolution. It was necessary to actively guide peasants to organize themselves, participate in the national revolution movement, go deep into the peasants and truly understand what peasants need and think. He fully recognized that peasants were an important force in the Chinese revolution in

The Complete Works of Lenin, Volume 42, Beijing: People's Publishing House, 1987, p. 347.

4 Selected Works of Mao Zedong, Vol. 2, Beijing: People's Publishing House, 1991, p. 532. 
Investigation Report on Human Peasant Movement, and it's needed to quickly change the wrong treatment of peasants by the revolutionary authorities. The main driving force of the Chinese revolution was the peasant class, the proletariat, and the petty bourgeois. At the same time, Mao Zedong mentioned in the article Talks on the Coalition Government: "Farmers - this is the predecessor of workers." In the future, there will be tens of millions of peasants entering the city and entering the factory." 5 Mao Zedong believed that peasants were the main forces to develop democratic politics, provide market raw materials and carry out cultural construction. After the establishment of the land, Mao Zedong attached great importance to the land issue. He proposed the general policy for agrarian revolution at the August 7th meeting. The main method then is to solve the land problem by means of "populist" revolutionary means, confiscating the land of large and middle landlords and distributing it to tenants and landless peasants. It also proposed to "minus the rent for the small landowners. The rent rate of small farmland owners should be set by the farmers' association. All so-called public property: temples, ethnic temples and other land should be confiscated and distributed to landless peasants." In 1928, The Jinggangshan Land Law was enacted, and then the Xingguo Land Law was promulgated to correct the wrong formulation of Jinggangshan Land Law. In 1931, the Central Bureau of the communist party of China (CPC) of the Soviet Union issued a notice entitled "Land Issues and Anti-funds Strategy" notice, which stated that "peasants are small private producers and it is their nature to keep private ownership". "They rose up enthusiastically to take part in the agrarian revolution, and their purpose was not only to obtain the right to use the land, but also, in the main, to acquire the ownership of the land" and so on.

\section{B. Educating Farmers to Improve Farmers' Quality}

In the 1930s, China was faced with internal and external issues and cultural decline, and people were suffering, too. The patriots represented by Yan Yangchu, Lu Zuofu, and Liang Shuming carried out a series of relief rural construction, but ultimately failed to really change the face of the Chinese countryside. The first generation of central leadership of the Communist Party of China with Comrade Mao Zedong as its core believes that China is in urgent need of a "cultural revolution" to educate farmers based on China's reality. Mao Zedong deeply recognized the duality of the peasants. On the one hand, they were deeply oppressed by landlord class and imperialism. On the other hand, they were limited by their own class and had certain class limitations. How to change this limitation? Mao Zedong believes that education can be used to make changes. With regard to the guidelines for peasant education, Mao Zedong firmly pointed out that it must be guided by communist ideology, and no other class's cultural ideology can take the role. In January 1934, the Second National Soviet Congress put forward the general policy of "educating the laboring masses in the spirit of communism. It is to make culture and

Selected Works of Mao Zedong, Vol. 3, Beijing: People's Publishing House, 1991, p. 687. education to serve for the revolutionary struggle and class struggle, to link culture and education with labor, and to make the broad masses of the Chinese people enjoy the happiness of civilization." In 1940, he mentioned the characteristics of the institutional revolution and the culture of new democracy in the New Democracy. In 1957, he mentioned in On the Correct Handling of Contradictions among the People, it's needed to cultivate comprehensive workers with socialist consciousness and culture who have developed both morally, intellectually and physically. As for the principles of peasant education, Mao Zedong believes that the principle of voluntariness, integration of production and life must be adhered to in the process of education. As for the contents of peasants' education, Mao Zedong believes that it was necessary to teach peasants the common contents that were easy for them to understand, remember and apply, and popularize political education, scientific and technological education, cultural education and health education. As for the form of education, Mao Zedong believed that it could be through slogans, pictures and speeches, night schools and so on.

\section{Establishing Cooperatives and Giving Play to the Power of Farmers}

As for the principles of cooperatives, Mao Zedong believes that everything should proceed from reality, respect public opinion, cooperate on an equal footing and run cooperatives diligently and frugally. As for issues concerning the forms, stages and requirements of cooperatives, Mao Zedong believed that the development of cooperatives should adhere to the principle of gradual progress and certain development stages and steps. At the same time, he believed that the forms of cooperatives should be diversified. In March 1927, Mao Zedong mentioned the three types of cooperatives: consumption, trafficking, and credit in the article Investigation Report on Human Peasant Movement. He talked about production, consumption, transportation, credit, handwork and other comprehensive cooperatives in Organizing. As for the planning of cooperatives, Mao Zedong believed that different regions should formulate different development plans, and they could not do it too fast. On the issue of the role of cooperative, Mao Zedong emphasized at the Second National Congress of the Chinese Soviets: "The movement of organizing the broad masses in cooperatives has also made remarkable achievements...The organization of the masses was becoming more closely related to the bureau of foreign trade, the commissariat, and the Soviet shops, and they were receiving from the Soviet government powerful assistance in human and financial terms."

\section{THE MODERn ENLIGHTENMENT OF MAO ZEDONG'S THOUGHT ON PEASANT TO PRACTICE THE STRATEGY OF RURAL REVITALIZATION}

\section{A. Adhering to the People-centered Development Thinking and Improving Farmers' Sense of Well-being}

History and practice have fully proved that the people are the heroes of the Times, and that the people have created and 
developed history. Taking the people as the center is the consistent style and proposition of the Communist Party of China. During the period of revolution and construction in China, the first-generation central collective leadership of the Communist Party of China with Comrade Mao Zedong as the core set out from China's national conditions, based on the fact that China is an agricultural country, peasants occupy the country's main population, and serve as the main force of revolution, made comprehensive planning and attached great importance to the masses, and introduced a series of policies to benefit farmers and the people, fully mobilizing the peasants' enthusiasm in national independence and people's liberation movement, and turning the peasants into masters. The second-generation central collective leadership of the Communist Party of China with Comrade Deng Xiaoping as the core firmly grasp the basic national conditions that China is in the primary stage of socialism and will remain so for a long time to come, and profoundly put forward the "three favorable" standards: whether it is conducive to developing the productive forces of the socialist society, whether it is conducive to enhancing the comprehensive national strength of the socialist country, and whether it is conducive to improving the living standards of the people. The central collective leadership of the Communist Party of China with Comrade Jiang Zemin at the core emphasizes on the basis of new historical conditions and practices: 'The historical materialism that believes that the masses are true heroes cannot be abandoned' and puts forward the "three represents" important thought. The Party Central Committee with Comrade $\mathrm{Hu}$ Jintao as general secretary put forward the people-oriented science outlook on development, repeatedly stressed the close ties between the party and the people, and did a good job in mobilizing and guiding the masses. Since the 18th National Congress of the Communist Party of China, the Party Central Committee with comrade $\mathrm{Xi}$ Jinping as the core has adhered to the Marxist historical materialism, inherited and developed Mao Zedong's peasant ideology, paid more attention to peasants, adhered to the people-centered development ideology, and always gave priority to pheasants, continued to serve the people wholeheartedly, strengthen ability to perform duties, and embody the people-centered development philosophy in all fields and major links.

In the new era, it is of crucial significance to continue to insist Mao Zedong's emphasis on peasants' interests, maintain the principal position of the people, and adhere to the people-centered development thought in implementing and practicing the rural revitalization strategy. First of all, great importance must be attached to peasants, and their dominant position must be adhered. Under the conditions of the new era, China's rural development faces a series of new challenges and new problems. To meet the challenges, solve the problems, it is a must to improve the level of villagers' autonomy, and promote rural economic development, make "farmers' pockets and heads" rich. ${ }^{6}$ To realize the comprehensive revitalization of industries, talents, culture,

6 Wang Yupeng, Meng Baoqin: The Contemporary Value of Mao Zedong's View of Peasants in the Vision of Rural Revitalization Strategy, Mao Zedong Thought Study, 2018(5). ecology and organizations, the most crucial thing is to rely on the endogenous power of farmers to stimulate rural revitalization. Who can shoulder the burden of rural revitalization? Who would benefit from the revitalization? How to make the revitalization? This is the main line and premise of implementing the rural revitalization strategy. Agriculture is the national foundation of China, and farmers occupy the main force of the population. In implementing the rural revitalization strategy, it's a must to adhere to the people-centered development ideology, attach importance to the peasant's dominant position, and give play to the peasants' initiative spirit, respect the wishes of the peasants, let go of the people, realize the self-management and selfservice of the peasants, further improve the sense of belonging, responsibility and mission of the peasants. Secondly, it's needed to pay attention to people's livelihood and protect the interests of peasants. During the Mao Zedong period, agrarian revolution and reform were carried out, and the fundamental interests of the peasants were always concerned. In the new era, in the face of complicated domestic and international environments, it's a must to pay more attention to agricultural production and pay close attention to the issue of land. The report of the 19th National Congress of the Communist Party of China mentioned: "Deepening the reform of rural land system, improving the contracted land, the system of separation of powers keeps the land contracting relationship stable and long-lasting. After the second round of land contracting expires, it will be extended for another 30 years." 7 Such new ideas and measures have calmed the people's hearts and minds and stabilized people's livelihood. In addition, the current targeted poverty alleviation strategy, rural living environment improvement, promotion of the "rural toilet revolution", rural e-commerce, accelerating the implementation of rural drinking water consolidation and upgrading project and completing a new round of rural power grid upgrading mentioned in the 2019 government report, etc., are important measures to meet people's needs, improve people's lives, and ensure and improve people's livelihood.

\section{B. Developing Farmers' Professional Cooperatives, Organizing Farmers to Help Rural Revitalization}

During the Chinese revolution, the peasants were truly organized for the sake of national independence and people's liberation, and the peasants' main role was fully exerted, and the peasants' enthusiasm for production was mobilized, so that the human and material effects were maximized and optimized under the conditions of extremely scarce production materials. The first-generation central collective leadership of the Communist Party of China with Comrade Mao Zedong as the core developed cooperatives and conducted detailed expositions on the principles, forms, functions, and plans of cooperatives. The second-generation central collective leadership of the Communist Party of China with Comrade Deng Xiaoping as the core proposed

Decisive Victory in Building a Well-off Society in an All-round Way to Win a Great Victory in Socialism with Chinese Characteristics in the New Era, People's Daily, October 28, 2017. 
the "two leap" thoughts and deeply explained the principles of cooperatives against the background of reform and opening up. The central leadership group with Jiang Zemin as the core focused on the role of cooperatives. The Party Central Committee with Comrade $\mathrm{Hu}$ Jintao as general secretary based itself on farmers and insisted on legislating for cooperatives. Since the 18th National Congress of the Communist Party of China, the Party Central Committee with comrade $\mathrm{Xi}$ Jinping as the core has emphasized the importance and necessity of developing farmers' professional cooperatives in many speeches and occasions, and proposed the idea of "trinity system", insisting on the practice of cooperatives, emphasizing the functions and roles of cooperatives, and the way of development.

In the new era, it is of profound significance and influence to draw on Mao Zedong's cooperative thinking on the implementation and practice of rural revitalization strategy. First, it is an important way to solve the main contradiction in China's society. The report of the 19th National Congress of the Communist Party of China writes: "The contradiction between the people's growing need for a better life and unbalanced development". Specialized farmer cooperatives can organize and concentrate farmers, give full play to their collective strength, and help narrow the gap and reduce the differentiation. Second, it can effectively alleviate the contradiction between farmers and the market. On March 8, 2019, General Secretary Xi Jin mentioned in the deliberation of the Henan delegation at the Second Session of the 13th National People's Congress: "It's a must to develop various forms of agricultural operations on an appropriate scale, give high priority to the development of family farms and farmers' cooperatives, and support the integration of small farmers with modern agriculture." 8 Farmers' professional cooperatives organize farmers to achieve large-scale development, which can raise risk awareness and effectively reduce and overcome the risks faced by individual farmers in facing large markets. Third, the overall goals and overall requirements of the rural revitalization strategy can be realized. Farmers' professional cooperatives can effectively realize the integration of the first, second and third industries and promote the development of the service industry. It adheres to the concept of green development in the production process, effectively reduce pollution, realize ecological development, and build tourism and leisure agriculture, and deepen the education of farmers to improve the quality of farmers through various ways. Fourth, it is an important starting point for the structural reform of the rural supply side. As far as the supply side is concerned, farmers' professional cooperatives can provide consumers with green, pollution-free and high-quality agricultural products. On the demand side, with the rapid improvement of productivity, the needs of the people are diversified, not only focusing on material needs, but also pursuing the spirit result. As a participant, promoter, contributor and beneficiary of the market, farmers' professional cooperatives can change the production

Xi Jinping, Li Keqiang, Wang Hu'ning, and Han Zheng participated in the deliberation of some delegations of the National People's Congress respectively, People's Daily, March, 9, 2019. structure according to market changes in time to meet the growing needs of the people. In addition, through the processing and utilization of agricultural scientific and technological means, farmers' professional cooperatives can further improve agricultural productivity.

\section{Strengthening the Continuing Education of Farmers and Cultivating New Professional Farmers}

The notion of new type of professional peasant is proposed relatively to the "identity peasant" in traditional Chinese society. The new professional peasant has the characteristics of strong political awareness, excellent performance in business, strong integrity, correct theoretical basis, loving of agriculture, technology-savvy and good management. Cultivating a new type of professional farmers is an inevitable requirement and objective choice for implementing the targeted poverty alleviation strategy, deepening the reform of rural economic system, building a big learning country, building a moderately prosperous society in all respects, and realizing the Chinese dream of great rejuvenation of the Chinese nation. In recent years, the country has taken multiple measures to improve the quality of farmers. The level of education has improved markedly. However, there still exist a gap with the requirements for building a learning-oriented country and realizing the great rejuvenation of the Chinese nation. According to the China Statistical Yearbook of 2018, as of 2017, there were 56,152 people who had not attended school in China. There are 952,893 people over the age of 15 , among which 460,221 are illiterate people, accounting for $4.85 \%$. 9 It is urgent to accelerate the cultivation of new professional farmers and build a learning-oriented country. Poverty alleviation is combined with supporting aspirations and wisdom. Education is the basic way to deepen targeted poverty alleviation, change farmers' mental outlook and improve their quality. Comrade Mao Zedong expounded on the guiding ideology, educational principles, educational content and form of peasant education. These educational ideologies have important reference significance for cultivating new professional peasants. First of all, as far as the guiding ideology of peasant education is concerned, it is necessary to adhere to Marxism-Leninism, Mao Zedong Thought, and the theoretical system of socialism with Chinese characteristics as a guide. History and practice have repeatedly proved that China is a socialist country and it must adhere to the guiding position of Marxism in ideology. Secondly, in terms of peasant education, it's a must to adhere to the principle of voluntariness and equality, and no compulsory or forced measures are accepted. The new professional farmer education must be a voluntary action. Next: the content of farmers' education. First, it's possible to actively introduce the Marxism to the peasants in a way that is popular with the people, strengthen the ideological leadership, constantly strengthen the ideals and beliefs of the new professional peasants, continue to promote Marxism contemporary, popular and sinicized, and truly bring Marxism close to the agricultural and rural realities and close to the peasants. Second, it's needed to strengthen agricultural policy

9 http://www.stats.gov.cn/tjsj/ndsj/2018/indexch.htm 
education, deepen pheasants' understanding of the state's policy on "agriculture, rural areas and farmers", and national policy orientation, timely and effectively control agricultural development. Third, in terms of education, it's a must to adhere to the principle of combining theory with practice, and offer scientific education in line with local conditions. Learning can be done through $\mathrm{TV}$, radio, Internet plus, websites, symposiums and seminars, etc. At the same time, students should get out of class and books and go deep and solid. For individual students with difficulties, it's needed to formulate scientific and reasonable methods according to their own conditions. Finally, teachers can invite experts and scholars from universities, government personnel, decision makers, technicians and other relevant personnel to give explanation and training, so as to realize the revitalization of talents.

\section{CONCLUSION}

China is a big agricultural country, with farmers accounting for the vast majority of the population. Accelerating agricultural modernization is a crucial issue of the times and a realistic task. Mao Zedong's thought on peasant provided a theoretical guidance and reference for solving the problems of agriculture, rural areas and farmers and implementing the strategy of rural revitalization in the new era.

\section{REFERENCES}

[1] Selected Works of Marx and Engels, Vol. 4, Beijing: People's Publishing House, 1995, p. 484. (in Chinese)

[2] The Complete Works of Lenin, Volume 42, Beijing: People's Publishing House, 1987, p. 347. (in Chinese)

[3] Selected Works of Mao Zedong, Vol. 2, Beijing: People's Publishing House, 1991, p. 532. (in Chinese)

[4] Selected Works of Mao Zedong, Vol. 3, Beijing: People's Publishing House, 1991, p. 687. (in Chinese)

[5] Wang Yupeng, Meng Baoqin: The Contemporary Value of Mao Zedong's View of Peasants in the Vision of Rural Revitalization Strategy, Mao Zedong Thought Study, 2018(5). (in Chinese)

[6] Decisive Victory in Building a Well-off Society in an All-round Way to Win a Great Victory in Socialism with Chinese Characteristics in the New Era, People's Daily, October 28, 2017. (in Chinese)

[7] Several Opinions of the Central Committee of the Communist Party of China and the State Council on Adhering to the Priority of Agricultural and Rural Development to Do a Good Job in the "Three Rural Issues", People's Daily, February 20, 2019. (in Chinese)

[8] Xi Jinping, Li Keqiang, Wang Hu'ning, and Han Zheng participated in the deliberation of some delegations of the National People's Congress respectively, People's Daily, March 9, 2019. (in Chinese) 